\title{
Penerapan Senam Nifas Terhadap Penurunan Tinggi Fundus Uteri: Literature Review
}

\author{
Irkhamna Restyani ${ }^{1 *}$, I Isyti'aroh ${ }^{2}$, Windha Widyastuti ${ }^{3}$ \\ ${ }^{1,2,3}$ Program Studi Diploma Tiga Keperawatan, Universitas Muhammadiyah Pekajangan \\ Pekalongan, Indonesia \\ *email:fikes.umpp@gmail.com
}

\begin{abstract}
Postpartum exercise is a series of movements performed after childbirth so that the muscles that have been stretched during pregnancy and childbirth can return to their normal condition, and the fundal height can decrease well. The purpose of this scientific work was to determine the decreasing fundal height in postpartum mothers doing and not doing postpartum exercise. This was a literature review of three articles taken from Google Shcolar with "postpartum exercise" and "fundal height" as the keywords, in the form of fulltext articles, published in 2013, 2017, and 2019. The respondents of the three articles were 100 postpartum mothers. The result of the analysis showed the decreasing fundal height occured to $43(83 \%)$ respondents doing postpartum exercise and $10(21 \%)$ respondents not doing the exercise. The conclusion was that fundal height could decrease better in respondents who did postpartum exercise than those who did not do the exercise. Therefore, health care providers are expected to be able to teach postpartum exercise to postpartum mothers so that their fundal height can decrease better.
\end{abstract}

Keywords:postpartum mother, postpartum exercise, fundal hight

\begin{abstract}
Abstrak
Senam nifas adalah serangkaian gerakan yang dilakukan setelah melahirkan supaya otot-otot yang mengalami peregangan selama kehamilan dan persalinan dapat kembali seperti semula diikuti dengan penurunan tinggi fundus uteri. Tujuan penulisan adalah untuk mengetahui penurunan tinggi fundus uteri pada ibu postpartum yang melakukan dan tidak melakukan senam nifas berdasarkan literature review. Desain karya tulis ilmiah berupa literature review dengan jumlah artikel tiga yang diambil dari laman jurnal google scholar dengan kata kunci "senam nifas" dan "tinggi fundus uteri" berupa artikel fulltex,berjumlah 3 arikel yang terbit tahun 2013, 2017 dan 2019. Responden dari ketiga artikel sebanyak 100 responden. Hasil dari literature review ketiga artikel menunjukkan perbedaan penurunan tinggi fundus uteri kategori baik yaitu sejumlah $43(83 \%)$ pada responden yang melakukan senam nifas dan sejumlah $10(21 \%)$ pada responden yang tidak melakukan senam nifas. Simpulannya adalah responden yang melakukan senam nifas penurunan tinggi fundus uterinya lebih baik dibandingkan dengan yang tidak melakukan senam nifas. Saran bagi tenaga kesehatan diharapkan dapat mengajarkan senam nifas pada ibu postpartum agar penurunan tinggi fundus uteri lebih baik.
\end{abstract}

Kata kunci: ibu postpartum, senam nifas, tinggi fundus uteri

\section{Pendahuluan}

Postpartum masa nifas adalah keadaan yang dimulai setelah dua jam setelah persalinan sampai enam minggu setelah bayi lahir. Gangguan masa nifas salah satunya adalah gangguan proses pemulihan kondisi fisik ibu berupa proses involusi uteri.Gangguan proses involusi uteri yang tidak sempurna akan menyebabkan subinvousi uteri yang dapat mengakibatkan perdarahan. Dalam hal ini involusi uteri 


\section{Prosiding Seminar Nasional Kesehatan Lembaga Penelitian dan Pengabdian Masyarakat Universitas Muhammadiyah Pekajangan Pekalongan}

merupakan suatu proses dimana uterus kembali ke kondisi sebelum hamil dengan berat sekitar 60 gram. Proses ini dimulai segera setelah plasenta lahir akibat kontraksi otot-otot polos uterus. Guna mengatasi gangguan masa nifas khususnya dalam proses involusi uteri, maka dilakukan perawatan masa nifas salah satunya melalui senam nifas [1].

Senam nifas adalah sederetan gerakan tubuh yang dilakukan setelah melahirkan untuk memulihkan dan mempertahankan tekanan otot yang berkaitan dengan kehamilan dan persalinan [2]. Manfaat melakukan senam nifas adalah memulihkan kembali kekuatan otot dasar panggul, mengencangkan otot-otot dinding perut dan perineum, membentuk sikap tubuh yang baik dan mencegah terjadinya komplikasi. Komplikasi yang dapat dicegah sedini mungkin dengan melaksanakan senam nifas adalah perdarahan postpartum. Saat melaksanakan senam nifas terjadi kontraksi otototot perut yang akan membantu proses involusi yang dimulai segera setelah plasenta lahir [3].

Berdasarkan hasil penelitian yang dilakukan oleh Siregar (2014) tentang pengaruh senam nifas terhadap involusi uterus pada ibu postpartum primipara pervaginam di Klinik Bersalin Tutun Sehati Tanjung Morawa tahun 2013, hasil penelitian menunjukkan bahwa setelah ibu postpartum melakukan senam nifas selama 3 hari dengan gerakan yang benar, rata-rata penurunan tinggi fundus uterus yaitu $5 \mathrm{cmper}$ hari. Sedangkan penurunan tinggi fundus uterus pada ibu postpartum yang tidak melakukan senam nifas rata-rata $2 \mathrm{~cm}$ per hari. Dari hasil perhitungan dengan menggunakan uji-t menunjukkan bahwa ada pengaruh senam nifas terhadap involusi uterus pada ibu postpartum primipara hari 1-3 di Klinik Bersalin Tutun Sehati Tanjung Morawa [4].

Hasil penelitian lainnya yang dilakukan oleh Saputri, Gurusinga, dan Friska (2020) tentang pengaruh senam nifas terhadap proses involusi uteri pada ibu postpartum didapatkan hasil sebanyak 8 orang $(53,3 \%)$ dalam kategori cepat dan sebanyak 5 orang $(33,3 \%)$ dalam kategori normal pada ibu yang melakukan senam nifas, sebanyak 9 orang $(60,6 \%$ dalam kategori lambat, kategori normal sebanyak 4 orang $(26,6 \%)$ dan sebanyak 2 orang $(12,3 \%)$ dalam kategori cepat pada ibu yang tidak melakukan senam nifas [5].

Berdasarkan uraian di atas maka penulis tertarik untuk mambuat Karya Tulis Ilmiah dengan metode penulisan literature review dengan judul "Literatur Review tentang Penerapan Senam Nifas terhadap Penurunan Tinggi Fundus Uteri".

\section{Metode}

Metode yang digunakan dalam penelitian artikel ini adalah literature review. Pengumpulan data dilakukan dengan mencari jurnal penelitian yang sudah ada sejumlah 3 jurnal dengan topik yang samadilaman google scholar. Kata kunci yang digunakan yaitu "senam nifas" dan "penurunan tinggi fundus uteri". Jenis penelitian pada artikel yang direview menggunakan desain quasi experiment dan pra experiment, instrument yang digunakan adalah kuesioner yang dikategorikan (baik dan kurang). Kemudian memaparkan struktur penulisan publikasi penelitian dan dilakukan analisis data. 


\section{Prosiding Seminar Nasional Kesehatan Lembaga Penelitian dan Pengabdian Masyarakat Universitas Muhammadiyah Pekajangan Pekalongan

\section{Hasil dan Pembahasan}

\section{Hasil}

Hasil dari distribusi frekuensi penurunan tinggi fundus uteri pada reponden yang melakukan dan tidak melakukan senam nifas pada ketiga artikel yang direview dapat dilihat pada tabel berikut.

Tabel 3.1 Distribusi Frekuensi Penurunan Tinggi Fundus Uteri pada Responden yang Melakukan dan Tidak Melakukan Senam Nifas $(n=100)$

\begin{tabular}{llrrr}
\hline Penurunan Tinggi Fundus Uteri & \multicolumn{4}{c}{ Senam Nifas } \\
\cline { 2 - 5 } & Melakukan & \multicolumn{3}{c}{ Tidak Melakukan } \\
\cline { 2 - 5 } & $\mathrm{N}(52)$ & $\%$ & $\mathrm{~N}(48)$ & $\%$ \\
\hline Baik & 43 & $83 \%$ & 10 & $21 \%$ \\
Kurang & 9 & $17 \%$ & 38 & $79 \%$ \\
\hline
\end{tabular}

Berdasarkan hasil analisis data diatas dapat diketahui bahwa sejumlah 43 (83\%) responden yang melakukan senam nifas dan sejumlah 10 (21\%) responden yang tidak melakukan senam nifas mengalami penurunan tinggi fundus uteri kategori baik. Terdapat perbedaan penurunan tinggi fundus uteri kategori baik pada responden yang melakukan dan tidak melakukan senam nifas.

\section{Pembahasan}

Berdasarkan hasil literature review senam nifas berpengaruh terhadap penurunan tinggi fundus uteri pada ibu postpartum. Literature review diatas menunjukkan perbedaan penurunan tinggi fundus uteri yang signifikan pada ibu yang melakukan senam nifas dan yang tidak melakukan senam nifas dengan penurunan tinggi fundus uteri baik sebesar $83 \%$ pada ibu yang melakukan senam nifas. Sedangkan pada ibu yang tidak melakukan senam nifas dengan penurunan tinggi fundus uteri baik sebesar $21 \%$.Senam nifas adalah senam yang dilakukan sejak hari pertama melahirkan setiap hari sampai hari yang kesepuluh, terdiri dari sederetan gerakan tubuh yang dilakukan untuk mempercepat pemulihan keadaan ibu [6].

Persamaan pada ketiga artikel yang direview yaitu senam nifas dapat mempercepat penurunan tinggi fundus uteri pada ibu postpartum. Terlihat dari hasil analisis data terdapat perbedaan penurunan tinggi fundus uteri kategori baik pada ibu yang melakukan senam nifas dan tidak melakukan senam nifas. Senam nifas merupakan senam yang dilakukan pada ibu yang sedang menjalani masa nifas yang bertujuan untuk mempercepat pemulihan kondisi ibu setelah melahirkan, mencegah komplikasi yang mungkin terjadi selama masa nifas, memperkuat otot perut, otot dasar panggul dan memperlancar sirkulasi pembuluh darah serta membantu mempercepat proses involusi [7].

Melalui senam nifas atau gerakan latihan jasmani dapat meningkatkan kontraksi otot pada uterus. Dimana hal ini terjadi dari adanya peningkata ion kalsium di ektrasel yang berikatan dengan calmodulin, setelah calmodulin dan kalsium ini berikatan maka akan meningkatkan myosin kinase dan terjadi fosforilase pada kepala myosin yang berikatan dengan aktin sehingga terjadilah tarikan otot secara berkala sehingga terjadi 


\section{Prosiding Seminar Nasional Kesehatan 2021 Lembaga Penelitian dan Pengabdian Masyarakat Universitas Muhammadiyah Pekajangan Pekalongan}

kontraksi otot pada uterus setelah otot berkontraksi maka terjadi involusi uterus yang terus menerus. Dengan adanya kontraksi dan retraksi dari uterus yang terus menerus maka akan terjadi penjepitan pembuluh darah sehingga pembuluh darah pecah dan terganggulah peredaran darah ke uterus. Sehingga menyebabkan jaringan otot kekurangan zat yang diperlukan sehingga ukuran jaringan otot uterus akan mengecil dan membaik [8].

Hasil dari ketiga artikel yang direview sejalan dengan penelitian yang dilakukan oleh Anggraini dan Gustirini (2020) dengan judul "Pengaruh Senam Nifas dan Pijat Oksitosin Terhadap Involusi Uteri pada Ibu Postpartum" menunjukkan hasil bahwa terdapat perbedaan rerata yang bermakna pada penurunan tinggi fundus uteri antara kelompok perlakuan dan kelompok kontrol $(p<0,05)$ [9]. Penelitian lain yang dilakukan oleh Afriyani, Lailiyana, dan Metha (2018) dengan judul "Hubungan Senam Nifas dengan Involusi Uterus pada Ibu Postpartum Normal Di BPM Dince Safrina Pekanbaru Tahun 2017) menunjukkan ada perbedaan yang signifikan antara kelompok ibu postpartum yang melakukan senam nifas dan tidak melakukan senam nifas $(p=0,000)[10]$.

Proses involusi dapat dipengaruhi oleh beberapa faktor yaitu 1. Monilisasi dini yaitu kontraksi dan retraksi otot-otot setelah anak lahir, yang diperlukan untuk mengeluarkan isi uterus yang tidak diperlukan, sehingga ukuran uterus menjadi kecil. 2. Status gizi adalah tingkat kecukupan gizi seseorang yang sesuai dengan jenis kelamin dan usia. Ibu postpartum dengan status gizi yang baik akan mampu menghindari serangan kuman sehingga tidak terjadi infeksi dalam masa nifas dan mempercepat proses involusi uterus. 3. Menyusui, pada proses menyusui ada reflek let down dari isapan bayi merangsang hipofise posterior mengeluarkan hormon oxytosin yang oleh darah hormon ini diangkat menuju uterus dan membantu uterus berkontraksi sehingga proses involusi uterus terjadi. 4. Usia, pada ibu yang usianya lebih tua banyak dipengaruhi oleh proses penuaan, dimana proses penuaan terjadi peningkatan jumlah lemak. Penurunan elastisitas otot dan penurunan penyerapan lemak, protein, serta karbohidrat. Bila proses ini dihubungkan dengan penurunan protein pada proses penuaan, maka hal ini akan menghambat involusi uterus. 5. Parietas mempengaruhi involusi uterus, otot-otot yang terlalu sering teregang memerlukan waktu yang lama [6].

\section{Kesimpulan}

Berdasarkan literature review dari ketiga artikel dapat diketahui bahwa terdapat perbedaan penurunan tinggi fundus uteri kategori baik yaitu sejumlah 43 (83\%) responden yang melakukan senam nifas dan sejumlah 10 (21\%) responden yang tidak melakukan senam nifas. Kesimpulannya senam nifas dapat menurunkan tinggi fundus uteri pada ibu postpartum. Saran bagi tenaga kesehatan diharapkan dapat mengajarkan dan memberikan penyuluhan senam nifas pada ibu postpartum untuk mempercepat penurunan tinggi fundus uteri. Bagi ibu postpartum agar dapat melakukan senam nifas untuk mempercepat penurunan tinggi fundus uteri. 


\section{Prosiding Seminar Nasional Kesehatan $\mathbf{2 0 2 1}$ Lembaga Penelitian dan Pengabdian Masyarakat Universitas Muhammadiyah Pekajangan Pekalongan}

\section{Referensi}

[1] H.I. Indriyastuti, Kusumastuti, dan T. Aryanti, "Pengaruh senam nifas terhadap kecepatan involusi uterus pada ibu nifas di BPS Sri Jumiati kecamatan Buluspesantren kabupaten Kebumen",Jurnal involusi kebidanan, vol. 4, no. 8,pp. 33-46, 2014.

[2] R.Y. Astutik, Buku ajar asuhan kebidanan masa nifas dan menyusui. Jakarta Timur: CV. Trans Info Media

[3] S.H. Ineke, M. Murti, danS. Sumarni,"Pengaruh senam nifas terhadap tinggi fundus uteri dan jenis lochea pada primipara"Jurnal ilmiah bidan, vol. 1,no. 3, pp. 45-54, 2016.

[4] N. Siregar, "Pengaruh senam nifas terhadap involusi uteri pada Ibu post partum primipara pervaginam di Klinik Bersalin Tutun Sehati Tanjung Morawa tahun 2013",Jurnal ilmiah PANNMED, vol. 9, no. 1, pp. 1-7, 2014.

[5] I.N. Saputri, R. Gurusinaga, dan N. Friska, N. "Pengaruh senam nifas terhadap proses involusi uteri pada ibu postpartum"Jurnal kebidanan kestra (JKK), vol. 2, no. 2, pp. 159-163, 2020.

[6] E.S. Walyani, dan T.E. Purwoastuti, Asuhan kebidanan masa nifas dan menyusui (postnatal care). Yogyakarta: Pustaka Baru Press

[7] Hidayati, dan R. Gusrawati, "The influence of postpartum gymnastic on accelation of uterial involution and decreasing of pain in post partum patients in the midwifery room Lubuk Sikaping Hospital",Jurnal kesehatan prima nusantara Bukittinggi, vol. 9, no. 2, pp. 138-148, 2018.

[8] S.D. Sari, dan E. Safitry, "Pengaruh senam nifas terhadap tinggi fundus uteri pada ibu nifas di BPM Husniyati dan Nurtila Palembang", Cendekia medika, vol. 3,no. 1, pp. 41-46, 2018.

[9] I.A. Anggarini, danR. Gustirini, "Pengaruh senam nifas dan pijat oksitosin terhadap involusi uteri pada Ibu postpartum", Midwifery journal, vol. 5, no. 2, pp. 65-70, 2020.

[10] R. Afriyani, Lailiyana dan J.M. Metha, "Hubungan senam nifas dengan involusi uterus pada ibu postpartum normal di BPM Dince Safrina Pekanbaru tahun 2017",Jurnal ibu dan anak, vol. 6,no. 1, pp. 26-31, 2018. 